\title{
The Effectiveness of Warm Vinegar Compress in Lowering Children Body Temperature with Acute Febrile Illness
}

\author{
Sumy Dwi Antono \\ Health Polytechnic of Malang, Republic of Indonesia
}

\begin{abstract}
Fever is the body's response to disease by pyrogens and is characterized by an increase in set-point and activity of immune complex; set-point is the value of the critical temperature ranging from a temperature of $37.1^{\circ} \mathrm{C}$, someone is said to get a fever when their body temperature is above normal body temperature, $37.5^{\circ} \mathrm{C}$. The purpose of this study is to determine the influence of warm vinegar compresses on children's body temperature with acute fever. The research design is Quasi Experimental with pre-test and posttest design. The research subjects are 36 pediatric patients who experienced an acute febrile. The data were analyzed in univariate manner, to see the development of temperature after treatment, the data were presented in tabular form. Bivariate analysis is used to compare pre-test and post- test and also paired samples $t$ test, to analyze the results of experiments on the presence or absence of the influence of warm vinegar compresses and warm compresses on children's body temperature with acute fever. T test independent testing is to analyze differences. The average decrease of temperature in the group given warm water compress is $0.9^{\circ} \mathrm{C}$, from the results of this research. While, the average decrease in the group given warm vinegar compress is $1.4^{\circ} \mathrm{C}$. Based on the result of statistical test Paired Samples $t$-test, the researcher obtained data from the treatment of warm water compresses with the value of $t=16.047, p$-value $\leq 0$, it means that there is a significant difference in the average decrease in children body temperature with warm water compresses treatment. Based on the result of statistical test Paired Samples t-test, the researcher obtained data from the treatment of warm vinegar compresses with the value of $t=16.047$, p-value $\leq 0$, so there is a significant difference in the average decrease in children body temperature with warm vinegar treatment. Based on the result of statistical tests Independent t-test, the researcher obtained data from the treatment of warm water compresses compared to warm vinegar compress with the value of $t=-4.738$, p-value $\leq 0$, so to conclude there are significant differences on giving warm vinegar compresses and warm compress in 15 minutes. Warm vinegar compress is more effective than warm water compress to lower children's temperature with acute fever. In conclusion, there is a significant difference in average of decreased children's body temperature to warm vinegar compresses and warm water compresses. There is influence of warm vinegar compresses on children's body temperature changes with acute fever. There is a significant difference in average of decreased children's body temperature to warm vinegar compresses and warm water compresses, with a greater average decrease in body temperature in the treatment of warm vinegar compress than warm water compresses. Further researchers are recommended to concern more on the factors that influence fever in children so confounding variables can be controlled.
\end{abstract}

Keywords: compresses, warm vinegar, warm water, acute fever in children

\section{Introduction}

Fever is the body's response to disease by pyrogens and is characterized by an increase in set-point and activity of immune complex; set-point is the value of the critical temperature ranging from a temperature of $37.1{ }^{\circ} \mathrm{C}$, someone is said to get a fever when their body temperature is above normal body temperature, $37.5^{\circ} \mathrm{C}$ (Guyton and Hall, 2013).

Some areas in Indonesia such as East Java is related to illness due to acute fever. It is estimated that the incidence rate reached 12.04 per 100,000 population, 95\% in children under the age of 15 years. According to surveillance Ministry of Health of the Republic of Indonesia, the frequency of occurrence of fever in Indonesia is 15.4 per 10,000 population. There was an increasing number of patients, around $35.8 \%$, according to surveys of various hospitals in Indonesia from 1981 through 1986 (Suriadi, 2010).

Children are particularly vulnerable to high fever that cause symptoms such as febrile seizures and dehydration. Dehydrated or febrile seizures is affecting the children development and growth and may even cause death (Bradley $P$ and Jerry J, 2006). Moreover, the impact that may occur if the fever is not handled properly, it will cause brain damage, hyperpyrexia which would cause shock, epilepsy, mental retardation or learning disabilities (Andrea Reich, 2011).

There are two managements of fever: Pharmacology and Non-Pharmacology. For Pharmacology, antipyretic is usually given as drug. Antipyretic that widely used and recommended is Paracetamol, ibuprofen and Aspirin (acetosal) (Wilmana and Gan, 2007). In general, the side effects are in the form of erythema and urticaria and more severe symptoms such as fever and lesions in the mucosa, the extension of blood clotting; the long term use can lead to liver, encephalopathy and kidneys (nephropathy) disorders; acetosal / aspirin is not recommended for children because it can cause stomach bleeding and intestinal bleeding (Wilmana and Gan, 2007).

To lower the body temperature of children with acute febrile is by way of Non-Pharmacology, one of them is to do compression. IDAI (Indonesian Pediatric Association) describes the management of fever in children by way of medication physically to reduce fever, such as giving cold compresses, warm compresses, compress of alcohol, compress of herbs (herbs) and giving plenty of drink. American Academy of Pediatric recommends ways of handling fever, one of them is tepid sponging (warm 


\section{International Journal of Science and Research (IJSR) \\ ISSN (Online): 2319-7064 \\ Index Copernicus Value (2015): 78.96 | Impact Factor (2015): 6.391}

compresses) which is the most effective. Nurlaili Susanti in 2012 also done a research on the warm and cold compresses, her research entitled "Effectiveness of cold and warm compresses on the management of fever" which is published by Nurdin Milanisti on February 1, 2014. Using ice water (extreme temperature) would lead a loss of temperature regulation in the hypothalamus and will cause blood vessels to constrict and the heat is unable to escape causing vasoconstriction of skin surrounding organs (Guyton and Hall, 2013). Using alcohol can cause irritation and intoxication (poisoning) and even allergies (William Reusch, 2007).

One of the benefits and uses of vinegar for health and beauty is vinegar with $5 \%$ acetic acid levels that can be used as an antiseptic, and can be mixed into the water bath so that it will make your skin clean and fresh. (Orey \& Call, 2009).

The content of vinegar include: potassium, enzymes, vitamins $\mathrm{A}, \mathrm{B}$ and $\mathrm{C}$, minerals, and rich in anti-oxidants also contains beta carotene, bioflavonoids, calcium, magnesium, potassium, phosphorus, copper, iron, sulfur, fluorine, silicon, boron and pectin. It naturally balances the $\mathrm{pH}$ balance of the skin and the whole body. Vinegar as a restorative tonic improve blood circulation system of capillaries that nourish the skin and provide oxygenation, toning and even maintain skin elasticity, the skin's natural moisture and cells' regeneration; vinegar can improve blood circulation of the skin capillaries (Bragg, et al, 2011).

From the description above, the researcher is interested in conducting research that is "The Effect of warm vinegar compresses and warm water compresses on the decrease of children body temperature with acute fever".

\section{General Objective}

To know the effect of warm vinegar compresses and warm water compresses on the decrease in children body temperature with acute fever.

\section{Specific Objective}

In particular, this study aims to:

a) Measure children body temperature before and after giving warm water compress in 15 minutes.

b) Measure children body temperature before and after giving warm vinegar compress in 15 minutes.

c) Analyzing body temperature changes before and after giving warm water compress in 15 minutes.

d) Analyzing body temperature changes before and after giving warm vinegar compress in 15 minutes.

e) Analyzing children body temperature changes before and after giving warm vinegar compress and warm water compress in 15 minutes.

\section{Hypotheses}

1) There is an effect of warm water compresses on body temperature changes in children with acute fever

2) There is an effect of warm vinegar compresses on body temperature changes in children with acute fever

3) There are differences of warm vinegar compresses and warm compresses on children body temperature with acute fever

\section{Framework}


International Journal of Science and Research (IJSR)

ISSN (Online): 2319-7064

Index Copernicus Value (2015): 78.96 | Impact Factor (2015): 6.391

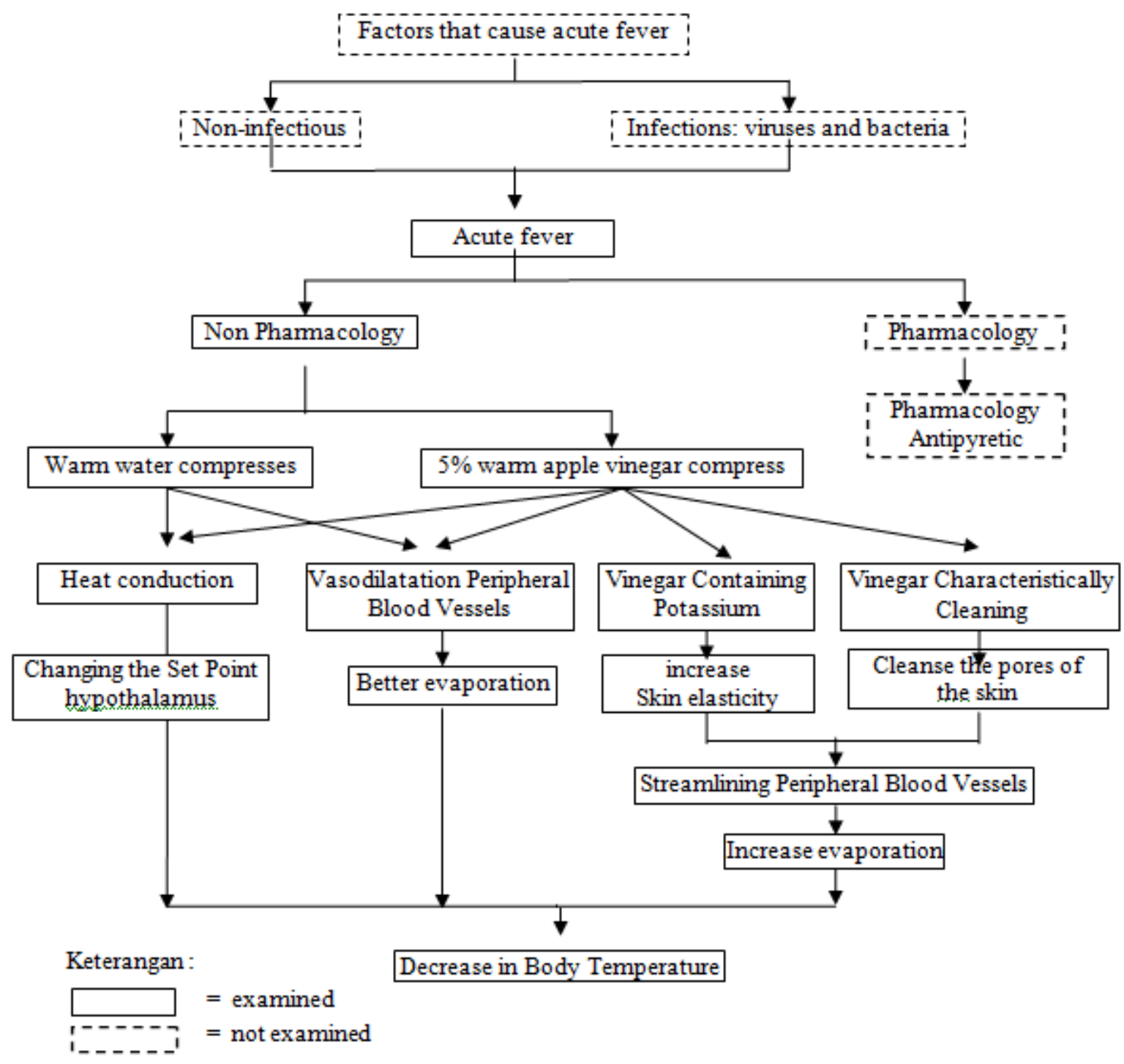

Figure 1 : Framework Concepts warm vinegar compresses influence the body temperature of children with acute febrile illness

\section{Method and Design}

This study uses Quasi Experimental with pre-test and posttest design as research design, the researcher then conducted an analysis on the differences of the influence of two independent variables, namely compresses of vinegar and warm water vinegar to the degree of decrease in children body temperature with acute fever.

The design is as follows:

\begin{tabular}{|c|c|c|c|}
\hline Subject & Pre test & Treatment $15 \mathrm{mnt}$ & Post test \\
\hline K - A & O & p.h & O1-A \\
\hline K - B & O & p.ch & O2-B \\
\hline & T'1 & T'2 & T'3 \\
\hline
\end{tabular}

\section{Information:}

a. $\mathrm{K}-\mathrm{A}$ : Subject (acute febrile children) treatment 1

b. K-B : Subject (acute febrile children) treatment 2

c. $\mathrm{O} \quad$ : Temperature observation before treatment

d. p.h : Treatment with warm water compresses

e. p.ch : Treatment with 5\% warm apple vinegar compress

f. O1-A : Temperature observation after p.h after 15 minutes

g. O2-B : Temperature observation after p.ch after 15 minutes

\section{Research Variable}

Variables Classification

a. Pediatric patients with acute fever (acute febrile illness) with axillary temperature between $37.2-39^{\circ} \mathrm{C}$ and has lasted for 1-2 days with complaints of dizziness, cough and colds

b. Patients do not experience seizures

c. Patients do not experience electrolyte balance disorders (dehydration)

d. Patients are fussy (cry constantly and do not want to sleep or eat)

e. Pediatric patients aged between 1-6 years

f. Pediatric patients with fever who are willing to participate in this research

\section{Result and Discussion}

\section{Result}

a. Frequency Distribution of Warm Water Vinegar Compress Treatment.

The data about the frequency distribution of vinegar compress treatment can be seen from the following diagram 


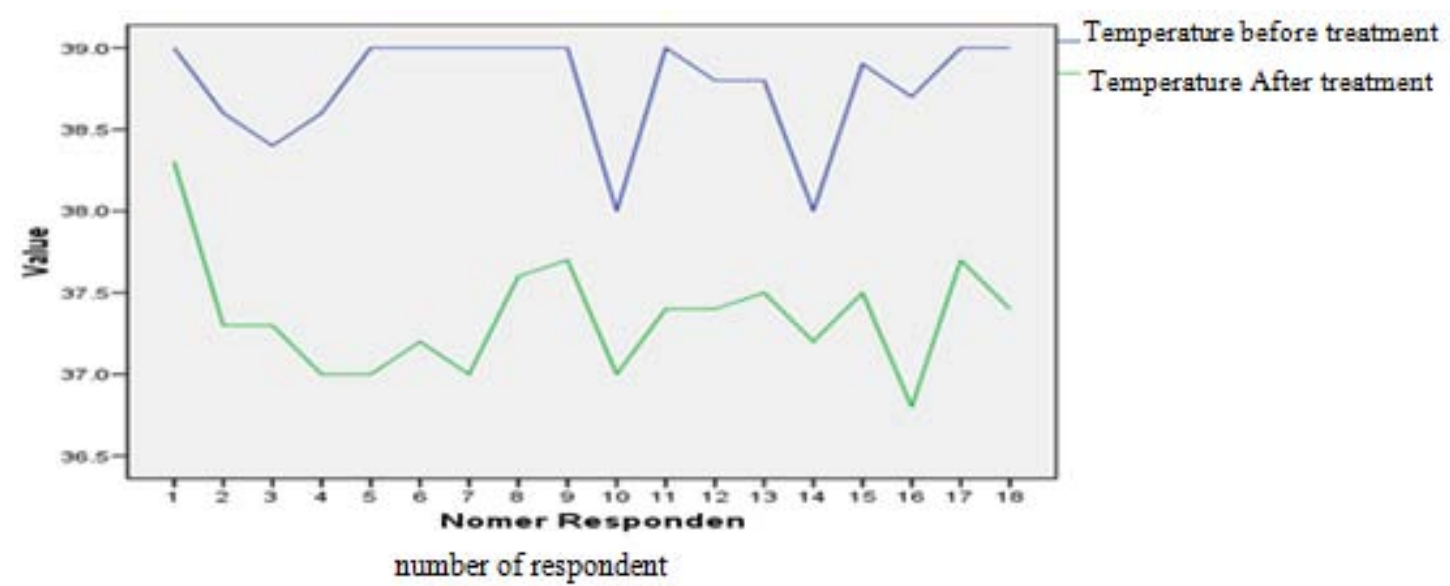

b. Frequency Distribution of Warm Water Compresses Treatment.

Figure 3.1 shows that there was a decrease in body temperature after receiving compress treatment for 15 minutes, the average decline is $1.41^{\circ} \mathrm{C}$ of the 18 respondents who have received warm water vinegar compress treatment.
Frequency distribution of warm water compresses treatment data can be seen from the diagram as follows;

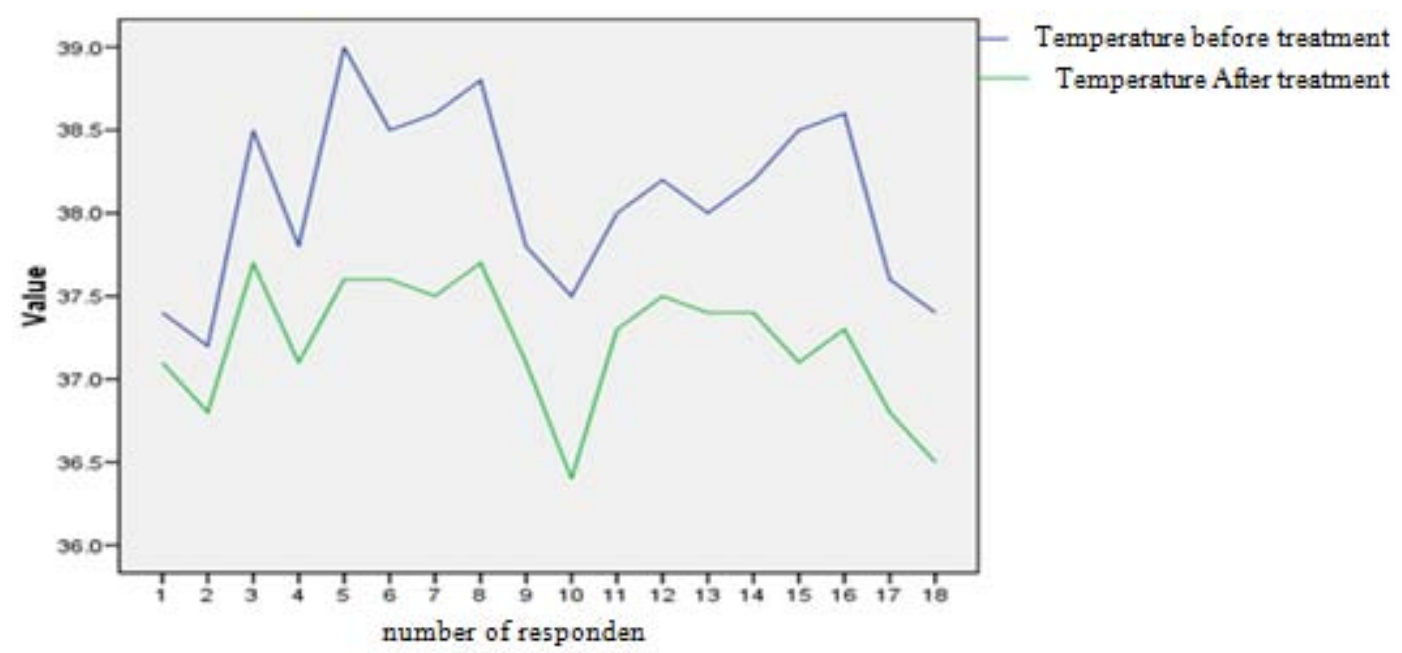

Figure 3.2: Frequency Distribution of Warm Water Compresses Treatment on Children Body Temperature with Fever Acute

Figure 3.2 shows that the body temperature decreased after receiving compress treatment in 15 minutes, the average decline is $0.87^{\circ} \mathrm{C}$ of the 18 respondents who have received warm water compresses treatment.

\section{c. Frequency Distribution of Warm Vinegar and Warm} Water Compresses Treatment.

Frequency distribution of warm vinegar and warm water compresses treatment data can be seen from the diagram as follows;

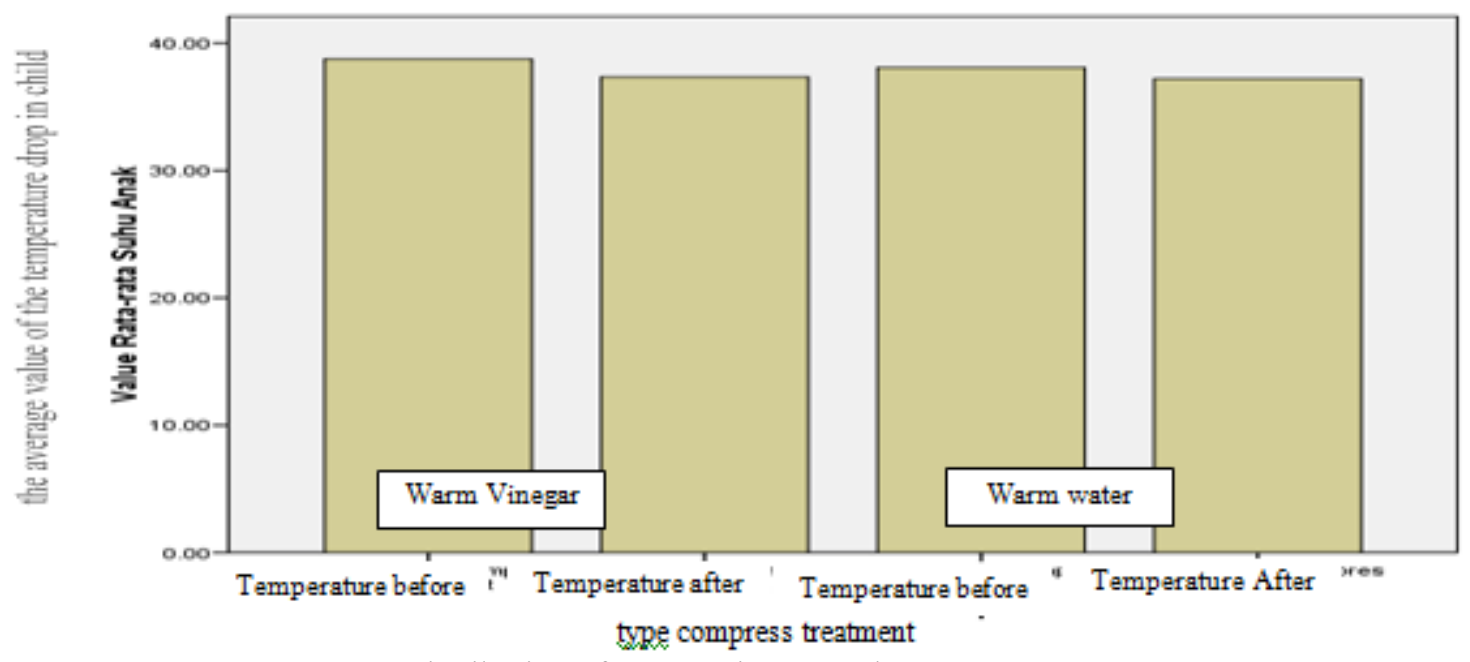

Figure 3.3: Frequency Distribution of Warm Vinegar and Warm Water Compresses Treatment on Children Body Temperature with Acute Fever

Volume 6 Issue 1, January 2017 www.ijsr.net 


\section{International Journal of Science and Research (IJSR) \\ ISSN (Online): 2319-7064}

Index Copernicus Value (2015): 78.96 | Impact Factor (2015): 6.391

Figure 3.3 shows that there was a decrease in body temperature after receiving warm vinegar compress treatment with the average decline $1.41^{\circ} \mathrm{C}$, and warm water compresses treatment with the average decline $0.87^{\circ} \mathrm{C}$. d. Frequency Distribution of Body Temperature Decrease after Warm Vinegar and Warm Water Compresses Treatment.

Frequency distribution of body temperature decrease after warm vinegar and warm water compresses treatment data can be seen from the diagram as follows;

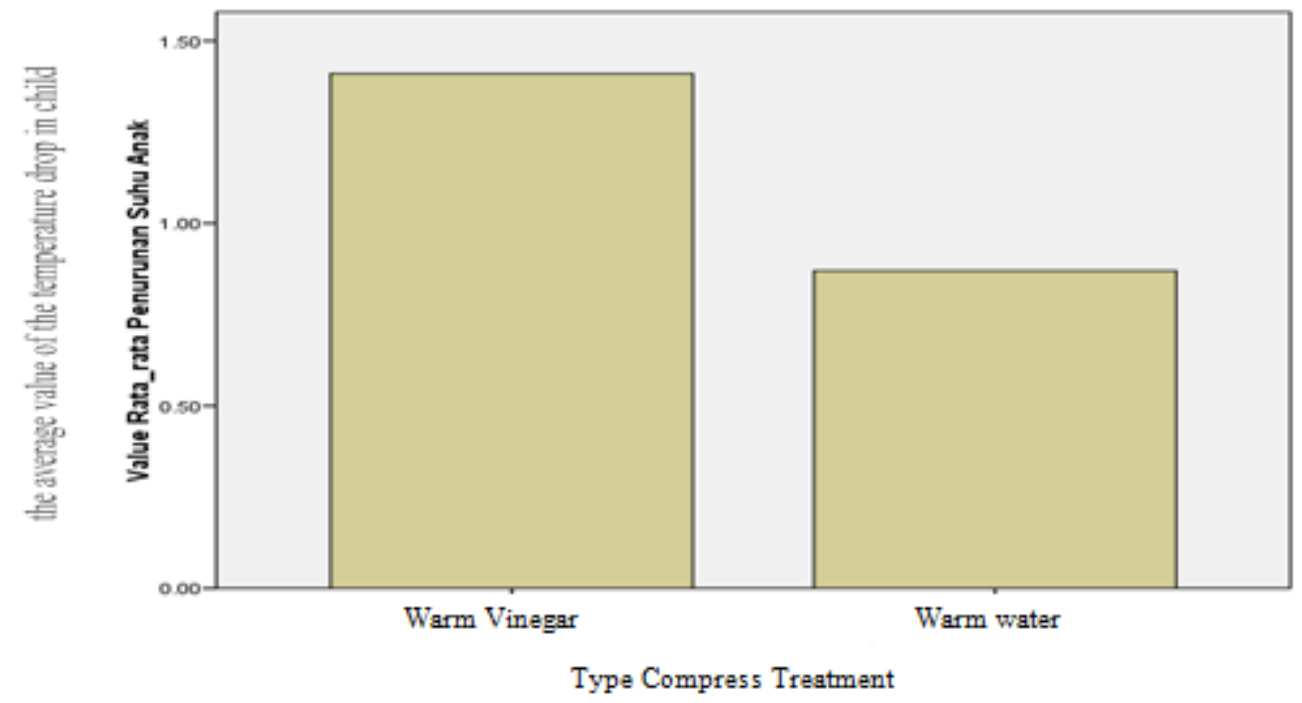

Figure 3.4: Frequency Distribution of Body Temperature Decrease after Warm Vinegar and Warm Water Compresses Treatment on Children Body temperature with Acute Fever

Figure 3.4 shows that the average decrease in body temperature after receiving warm vinegar compress treatment is $1.41^{\circ} \mathrm{C}$ and warm water compress treatment is $0.87^{\circ} \mathrm{C}$.

\section{e. Frequency Distribution of Body Temperature Decrease Effectiveness after Warm Vinegar and Warm Water Compresses Treatment.}

Frequency distribution of body temperature decrease effectiveness after warm vinegar and warm water compresses treatment data can be seen from the diagram as follows;

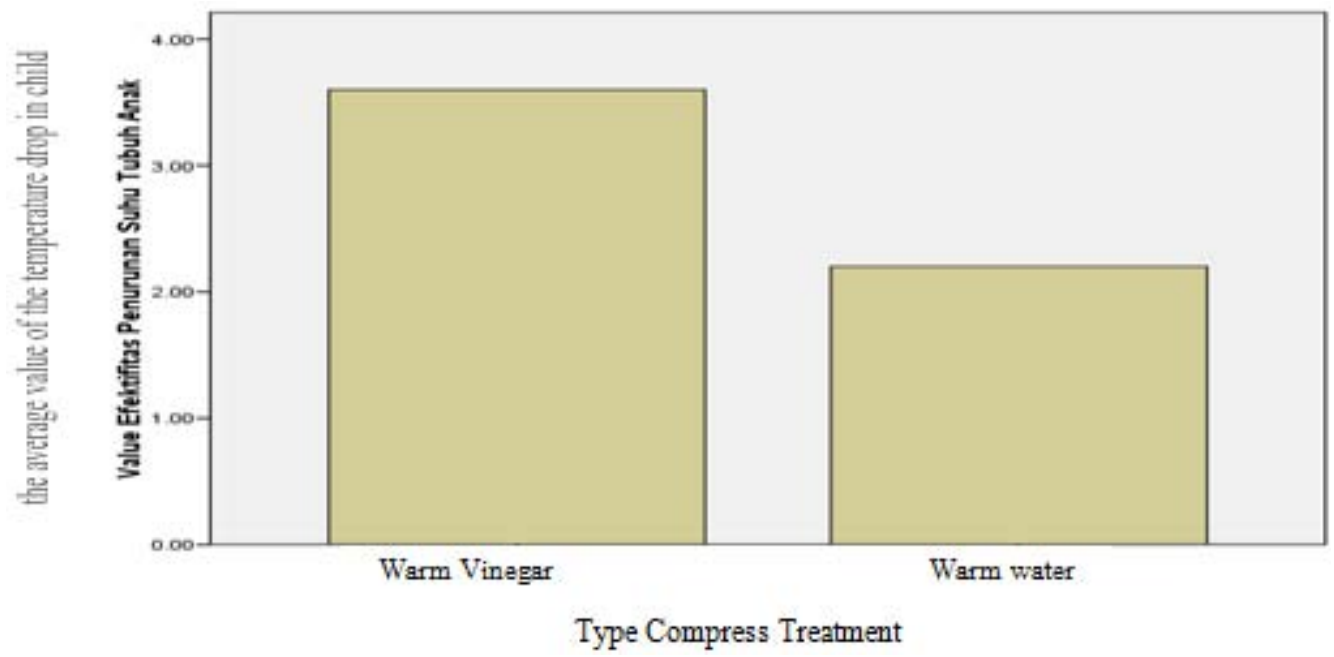

Figure 3.5: Frequency Distribution of Body Temperature Decrease Effectiveness after Warm Vinegar and Warm Water Compresses Treatment on Children Body temperature with Acute Fever

Figure 3.5 shows that of body temperature decrease effectiveness after receiving warm vinegar compress treatment is $3.6 \%$ and warm water compress treatment is $2.2 \%$. f. Changes in children body temperature before and after warm water compress treatment in 15 minutes.

Table 3.1 Results of Paired Samples t-test. Changes in children body temperature before and after warm water compresses treatment. 


\section{International Journal of Science and Research (IJSR) ISSN (Online): 2319-7064}

Index Copernicus Value (2015): 78.96 | Impact Factor (2015): 6.391

\begin{tabular}{|c|c|c|c|c|}
\hline Measurement & $\begin{array}{c}\text { The average } \\
\text { decline }\end{array}$ & $\begin{array}{c}\mathrm{St} \\
\mathrm{Dev}\end{array}$ & $\mathrm{t}$ & Significance \\
\hline $\begin{array}{c}\text { temperature before and after } \\
\text { warm water compress } \\
\text { treatment }\end{array}$ & $0,870 \mathrm{C}$ & 0,31 & 11,856 & 0,000 \\
\hline
\end{tabular}

Based on the result of statistical test Paired Samples t-test, the researcher obtained data from the treatment of warm water compresses with the value of $t=16.047, p$-value $\leq 0$, so the conclusion is there is a significant difference in the average decrease in children body temperature with warm water compresses treatment.

\section{g. Changes in children body temperature before and after warm vinegar compress treatment in 15 minutes.}

Table 3.2 Results of Paired Samples t-test. Children body temperature changes before and after warm vinegar compress treatment

\begin{tabular}{|c|c|c|c|c|}
\hline Measurement & $\begin{array}{c}\text { The } \\
\text { average } \\
\text { decline }\end{array}$ & $\begin{array}{c}\text { St } \\
\mathrm{Dev}\end{array}$ & $\mathrm{t}$ & Significance \\
\hline $\begin{array}{c}\text { Temperature before } \\
\text { and after warm vinegar } \\
\text { compress treatment }\end{array}$ & $1,41^{0} \mathrm{C}$ & 0,37 & 16,047 & 0,000 \\
\hline
\end{tabular}

Based on the result of statistical test Paired Samples t-test, the researcher obtained data from the treatment of warm vinegar compresses with the value of $\mathrm{t}=16.047$, $\mathrm{p}$-value $\leq$ 0 , so there is a significant difference in the average decrease in children body temperature with warm vinegar treatment.

h. Changes in children body temperature before and after warm vinegar compress and warm compress treatment in 15 minutes

Table 3.3 Independent t-test results. Children body temperature changes before and after receiving warm compresses and warm vinegar compresses treatment

\begin{tabular}{|c|c|c|c|c|}
\hline Measurement & $\begin{array}{c}\text { The } \\
\text { average } \\
\text { decline }\end{array}$ & $\begin{array}{c}\text { Average } \\
\text { difference }\end{array}$ & $\mathrm{t}$ & $\begin{array}{c}\text { Significance } \\
\text { 2-tailed }\end{array}$ \\
\hline $\begin{array}{c}\text { Temperature before } \\
\text { and after warm water } \\
\text { compress treatment }\end{array}$ & $0,87^{0} \mathrm{C}$ &,- 5444 & $-4,738$ & 0,000 \\
\hline $\begin{array}{c}\text { Temperature before } \\
\text { and after warm } \\
\text { vinegar compress } \\
\text { treatment }\end{array}$ & $1,41^{0} \mathrm{C}$ &,- 5444 & $-4,738$ & 0,000 \\
\hline
\end{tabular}

Based on the result of statistical tests Independent t-test, the researcher obtained data from the treatment of warm water compresses compared to warm vinegar compress with the value of $\mathrm{t}=-4.738, \mathrm{p}$-value $\leq 0$, so to conclude there are significant differences on giving warm vinegar compresses and warm compress in 15 minutes.

\section{Discussion}

\section{a. Warm Water Compress}

From the results of treatment of warm water compresses, there is a significant result to lower the temperature of body heat. At 15 minutes, the average decrease was $0.87^{\circ} \mathrm{C}$ of 18 children respondents who received warm water compresses treatment.

As has been pointed out by Wolf (1999) that the warm water is widely used by the public to lower body temperature of children who have fever and could prevent febrile seizures, warm stimulus on the surface of the skin is able to change the set-point in the hypothalamus, especially the anterior causing vasodilation, moreover the warm compress can increase evaporation, conduction and even radiation as it is written by Guyton and Hall (2013). Asmadi (2008) also said that compresses with warm water using a temperature of $34-37^{\circ} \mathrm{C}\left(93-98^{\circ} \mathrm{F}\right)$ or lukewarm can make the temperature outside felt warm and the body will interpret that the outside temperature is hot enough. Thus the body will lower the thermostat controls in the brain so as not to increase the body temperature again, which is also called the heat transfer by conduction system.

\section{b. Warm Vinegar Compresses}

The fact that can be concluded about the results of this study, children body heat temperature gradually dropped with an average decline $1.41^{\circ} \mathrm{C}$ of 18 respondents who do compress with warm vinegar for 15 minutes. Children respondents with warm water vinegar compress treatment indicate a very significant result in reducing fever, do not cause allergies and even make the children's body refreshed and comfortable, it may be because vinegar is excellent for compresses to lower body heat, warm water has also been widely used to compress fever, warm compresses have the effect of expanding blood vessels so the body dissipates heat faster. Compress treatment with warm water vinegar compress will increase evaporation process that is better and safer for the skin, in addition, a sense of warmth is also able to give a signal in the hypothalamus area so that the set-point move to adapt to the stimulus and lower the body temperature heat.

The experts also confirmed these conclusions, among others; Guyton and Hall (2013) described how the body temperature disappears from the surface of the skin, one of his writings is the warm external environment will make the peripheral blood vessels in the skin dilated or undergo vasodilation, it will also make the skin pores open that will ease the heat loss from the body, which is called evaporation. Barbara Rhegner (2003) also confirms this statement. American Academy of Pediatric recommends ways of handling fever, one of them is tepid sponging (warm compresses) which is the most effective.

Paul Bragg and Patricia Bragg, 2011 describes the content of vinegar and briefly explains the mechanism of the effect of the content of vinegar, according to them, the content of vinegar include: potassium, enzymes, vitamins $\mathrm{A}, \mathrm{B}$ and $\mathrm{C}$, minerals, and rich in anti-oxidants also contains beta carotene, bioflavonoids, calcium, magnesium, potassium, phosphorus, copper, iron, sulfur, fluorine, silicon, boron and pectin. It naturally balances the $\mathrm{pH}$ balance of the skin and the whole body. Vinegar 


\section{International Journal of Science and Research (IJSR) \\ ISSN (Online): 2319-7064}

Index Copernicus Value (2015): 78.96 | Impact Factor (2015): 6.391

as a restorative tonic improve blood circulation system of capillaries that nourish the skin and provide oxygenation, toning and even maintain skin elasticity, the skin's natural moisture and cells' regeneration; vinegar can improve blood circulation of the skin capillaries.

\section{c. Changes in Body Temperature after Warm Vinegar and Warm Water Compresses Treatment}

Data on average decrease in temperature indicates warm water vinegar compresses treatment is very influential in lowering children body temperature with fever, with an average decrease of $1.4^{\circ} \mathrm{C}$ with the effectiveness of $3.6 \%$ and warm water compresses treatment can also lower children body temperature with fever, with an average decrease of $0.87^{\circ} \mathrm{C}$ with the effectiveness of $2.2 \%$.

The blood vessels in the skin that is most important is the plexus venosus supplied by the flow of blood from the capillaries of the skin, is also well supplied through the arterial anastomosis arteriovenous. Giving warm compresses will make the vasodilatation of the veins or arteries itself so that high blood flow velocity in the skin cause heat conduction channeled from the body core to the skin to be very effective. The circulatory system of the skin which is already good then evaporate in 1 gram of water, that contains 0.58 kilocalories, and will disappear from the surface of the body, under normal circumstances the speed process of heat loss through evaporation is about 16-19 calories per hour, or about $8-9.5$ calories per 30 minute. More evaporation of sweat can transfer heat on the body more than 10 times the speed of the normal basal heat production. Guyton and Hall (2013).

Vinegar is also said to be a tonic restorative to the skin, which is to improve the blood circulation system of capillaries that nourish the skin and provide oxygenation, toning and even maintain the elasticity of the skin, keeping the skin's natural moisture and regeneration of skin cells, nourish the skin and the vinegar is able to improve blood circulation skin capillaries, so that the evaporation process is perfect. (Paul Bragg and Patricia Bragg, 2011)

\section{Conclusion and Recommendation}

\section{Conclusion}

Based on the results and discussion of the research on "The Effect of Warm Water Vinegar Compress on the Decrease of Children Body Temperature with Acute Fever (acute febrile illness)", it can be concluded as follows:

a) The average drop in temperature of the group given warm water compress is $0.9^{\circ} \mathrm{C}$.

b) The average drop in temperature of the group given warm vinegar compress is $1.4^{\circ} \mathrm{C}$.

c) There is an influence of giving warm water compresses on children body temperature changes with acute fever

d) There is an influence of warm vinegar compresses on children body temperature changes with acute fever

e) There is a significant difference in the average decrease of children body temperature with warm vinegar compresses and warm water compresses. The average decrease of body temperature on warm vinegar compresses is greater than on warm water compresses f) Warm vinegar compresses is more effective than warm water compresses to lower children's temperature with acute fever

\section{Recommendation}

a) Midwives are expected to function as educators who do health education about the dangers of children who experience high fever and are able to provide midwifery care for children with acute fever by giving management of warm vinegar compress to lower children body temperature.

b) Relevant institutions are expected to continuously perform health screening, and carry out health education about the dangers of children who experience high fever and cause febrile seizures and dehydration. Besides, institutions are expected to provide the facility of consultation on how to prevent children from experiencing acute fever, febrile seizures and dehydration due to high fever, and to be able to provide the management of fever in children independently at home or in the community by providing management of warm vinegar compress to lower children body temperature.

c) Further researchers are expected to pay more attention to the factors that affect acute fever in children so confounding variables can be controlled

\section{References}

[1] Abdullah (2012). Diktat Mikrobiologi Industri.

[2] Belachew, T. (2006). Acute Febrile Illness (AFI) For the Ethiopian Health Center Team (EPHTI).

[3] Bragg, et al. (2011). Apple Cider Vinegar. Bragg books and health products.

[4] Dalimartha, S. (2008). Atlas tumbuhan obat Indonesia. Jakarta: Pustaka Bunda.

[5] Davis, R. G., \& Davis, R. G. (2011). Animals, Diseases, and Human Health. Santa Barbara, California USA:

[6] Departemen Kesehatan Republik Indonesia, (1995). daftar komposisi zat gizi pangan indonesia. Jakarta: Departemen Kesehatan Republik Indonesia.

[7] Depkes_Republik_Indonesia. (2000). paradigma baru pelayanan kesehatan indonesia. Jakarta.

[8] Depkes_Republik_Indonesia. (2003). Keputusan Menteri Kesehatan RI Nomor 1076/MENKES/SK/2003 Tentang Penyelenggaraan Pengobatan Tradisional. Jakarta: Dirjen Komunitas dan Dirjen Binkesmas

[9] Dorland, W. A. N. (Ed.). (2002). Kamus Kedokteran Dorland (pertama ed.). Jakarta: EGC.

[10]Dwiyatmoko, B. (2001). Kebijakan dan Strategi Pengembangan Obat Asli Indonesia.

[11]Fathia Attia Mohammed dan Elsayeda Ibrahim Ahmed tahun 2012 pada International Journal of Science Keperawatan, Vol 2 nomor 4, 2012, hlm 38-48. Doi 10.5923/j.nursing.20120204.03

[12] Gay, L.R. dan Diehl, P.L. (1992), Research Methods for Business and. Management, MacMillan Publishing Company, New York

[13] Guyton, \& Hall, J. E. (Eds.). (2013). textbook of medical physiology), buku ajar fisiologi kedokteran (11 ed.). Jakarta: EGC.

[14]Kementerian_Kesehatan_RI. ( 2011). pedoman pengendalian infeksi saluran pernafasan akut. Jakarta. 


\section{International Journal of Science and Research (IJSR) \\ ISSN (Online): 2319-7064}

Index Copernicus Value (2015): 78.96 | Impact Factor (2015): 6.391

[15] Kozier, \& Barbara. (2004.). Fundamental Of Nursing : Concepts, Proses and Practice Upper Saddle River, N.J. Prentice Hall Health. Retrieved from http://www2.chemistry.msu.edu/faculty/reusch/VirtTxtJ $\mathrm{ml} /$ Questions/MOLEDITOR/carbhyd1.htm

[16] Mohammed, F. A., \& Ahmed, E. I. (2012). a comparison of vinegar compresses vs. cold water \& water with vinegar for treating of fever at tropical hospitals. International Journal of Nursing Science, 2(4), 38-46.

[17] Nertina, M. S. (2001). pedoman praktik keperawatan (A. Hany, Trans.). Jakarta: EGC.

[18] Ngastiyah (Ed.). (2005). Buku Perawatan Anak Sakit. Jakarta: EGC.

[19] Nursalam (2011). Asuhan Keperawatan Bayi dan Anak. Jakarta.: Salemba Medika.

[20] Orey, \& Call. (2009). The Healing Power of Vinegar. www.kensingtonbooks.com.

[21] Reich, A. (2011). Our Children Our Future. Children are the world's most valuable resource and its best hope for the future". In 1,000 days Your Children. http://www.dokteranakonline.com

[22] Reusch, W., El-Radhi, S., Carroll, J., \& Klein, N. (2009). Virtual Textbook of Organic Chemistry.

[23] Suriadi, \& Yuliani, R. (Eds.). (. 2001). Buku Pegangan Praktek Klinik Asuhan Keperawatan Anak (1 ed.). Jakarta: CV Sagung Seto. 